\title{
Globalization - a Cause or a Solution for Corona Economic Crisis
}

\author{
Razvan Catalin Dobrea ${ }^{*}, 1$, Iulian Gole ${ }^{1}$, and Ciprian Rotaru ${ }^{1}$ \\ ${ }^{1}$ Bucharest University of Economic Studies, 6 Piata Romana, Bucharest, Romania
}

\begin{abstract}
.
Research background: Since the extension of the Corona virus there are people saying that all this is happening because of globalisation, phenomena that diminished the control of states at the borders, lack of strong internal security rules, loose of political responsibility and decisions, etc. In this paper we investigated the situation from different economical perspectives and we clearly show the existence of positive effects of globalization. We will never know certainly enough at which percentage the current crisis results from a mismatch between the intensity of economic and human exchanges and the inability of public authorities to be prepared and take fast and appropriate decisions. It is well accepted that in a globalized world, interdependence prevails over sovereignty.

Purpose of the article: We will analyse if this reality is really one of the main problems which cause the current disaster. Nevertheless, it would be too easy to blame only the lacks of effective globalization, much complicated is to identify the problem and solve it. Searching if the globalization is the cause or the solution may be interesting since from the political side, we will see a wave of critics and sceptics, many politicians will try to reposition in order to gain visibility and votes.

Methods: Using descriptive and comparative analysis we demonstrate that societies may obtain greater benefits from cooperation, collaboration and integration, even in pandemic times.

Findings \& Value added: In a global world, we can see that borders do not protect against a pandemic and that all the major challenges facing humanity can only be solved by multilateral systems and by multilateral negotiation. We clearly demonstrated that global society has greater benefits from cooperation, collaboration and integration.
\end{abstract}

Keywords: globalization political; responsibility; leadership; pandemic cooperation

JEL Classification: F13; F63; H12; I15

\footnotetext{
* Corresponding author: razvan.dobrea@man.ase.ro
} 


\section{Introduction and research background}

Since the extension of the Corona virus everywhere in the world there are a number of voices saying that all this is happening because of globalisation, phenomena that diminished the control of states on the borders, lack of strong internal security rules, loose of political responsibility and decisions, etc. We will never know certainly enough at which percentage the current crisis results from a mismatch between the intensity of economic and human exchanges and the inability of public authorities to be prepare and act at a top level, generally speaking. It is well accepted that in a globalized world, interdependence prevails over sovereignty. We have to see if this reality is really one of the main problems which cause the current disaster. But it would be too easy to blame only the lacks of effective globalization, much complicated is to identify the problem and solve it. Searching if the globalization is the cause or the solution may be interesting since from the political side we will see a wave of critics and sceptics, many politicians will try to reposition in order to gain visibility and votes.

The solution is not always to blame the other. The Chinese government declared the Covid 19 eruption too late in January, when already there were plenty of voices announcing the reality about a new virus coming from Wuhan. On the other hand, President Trump together with other top US politicians suggested that the virus came from a Chinese military laboratory, but in reality the spread of the disease is due to a natural phenomenon, or at least there is no other scientific or other type of clear information to prove this.

It is a full-scale test of national public health policies and skills. It is tempting to exacerbate tensions for domestic political purposes (the presidential election in US are November 2020), but this strategy can be tricky when the economic damage has clearly been made worse by the two governments' mismanagement of the pandemic.

\section{Methods}

Globalization will adapt and continue to progress certainly; it cannot be other way to get back on track after such economy lockdown [1-4]. Speeches about self-sufficiency, shortening supply chains and questioning globalization will fade as soon as economic issues are taken into account. Stocks of drugs and masks can speed up responses during the next health emergency, but dependence on world trade cannot be avoided. Even if each country makes its own ventilators, the next crisis may well require dialysis machines instead or surgery laboratory. Therefore the cooperation is a solution and not the isolation therefore in the article we will demonstrate that globalization is the solution and not the cause of the crises [5-7].

Using descriptive and comparative analysis we demonstrate that societies may obtain greater benefits from cooperation, collaboration and integration, even in pandemic times. In this paper we analysed tariffs trade war consequences, we considered IMF data regarding worldwide economic growth expectation and we evaluated the long term export of good and services, patent evolution and FDIs in order to support the benefit of globalization in all cases.

\section{Results and Discussion}

The tariffs war made American and Chinese companies aware of the risks of relations between their governments and therefore they started explore alternatives. In fact, the shift in manufacturing production from China to Southeast Asia began many years ago when the wages of Chinese workers became too high. Today, Chinese companies are searching new markets in Asia, Europe and especially Africa [8]. The most important partner of Africa is China, with a commercial trade evaluated at $\$ 200$ billion/year. According to some researchers 
[9], more than 10,000 Chinese companies are currently doing business inside the African continent.

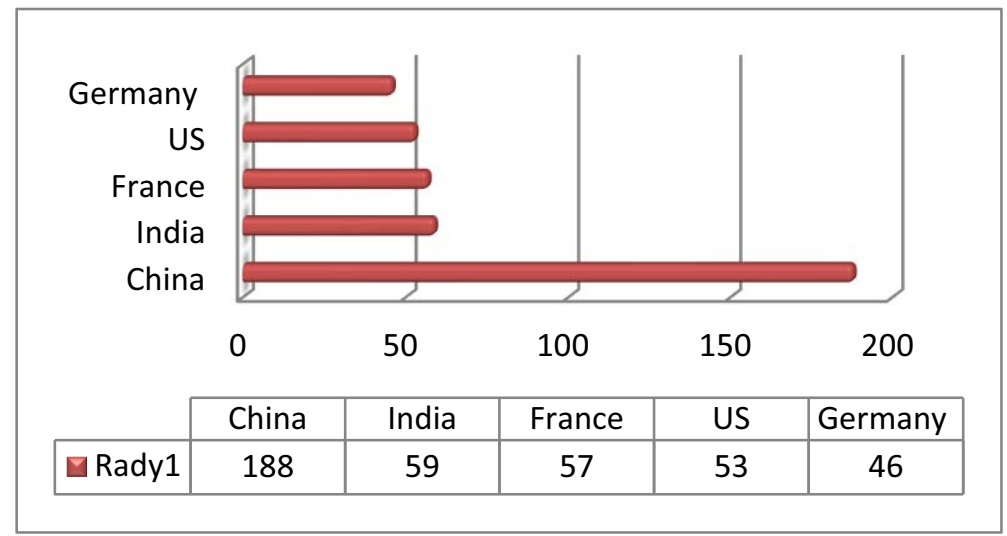

Fig. 1. Africa's best economic partners - goods trade, 2015, USD billion. Source: data from "The closest look yet at Chinese economic engagement in Africa" report, 2017.

Since 2005 , the value of their turnover has reached to almost $\$ 2$ trillion. In what concerned the overseas constructions markets, according to the same report, Africa is the most important client from China, even above other traditional Asian markets. But these are new chapters of globalization, in any case not the end of history.

The ideological battles will still continue. The first tangible results from China, and more generally from Asia, have highlighted the advantages of a comprehensive state control which has enabled governments to identify the development of the virus, control movements and better contain the spread. However, the Chinese government's lack of transparency may have allowed the spread of the virus at the start of the epidemic and eroded confidence in the government. A new debate around civil liberties will therefore emerge to assess the benefits of an even greater sharing of health-related data in order to manage future pandemics, but it will be an adjustment rather than an adoption of authoritarian political models. The confrontation for world leadership will be postponed. For now, the two countries will be too busy repairing the internal damage rather than paying particular attention to international projects. It looks like China will emerge from the crisis with better growth figures if the IMF forecasts are correct, but the limits of the global scope of this growth remain obvious. One of the main goals of expanding its influence through the "Belt and Road" initiative is now facing years of restructuring. On the other hand, EU is also facing same difficulties in order to restart the commercial activity, few countries having already their economy contracted even before the crises. According to IMF data, the China will slow down its growing in 2020 but still will remain on the positive side will all the other big economies will suffer important loses. Hopefully the recovery will be fast, but this is remaining to be seen.

Table 1. GDP economic growth expectations

\begin{tabular}{|c|c|c|c|}
\hline & $\mathbf{2 0 1 9}$ & $\mathbf{2 0 2 0}$ & $\mathbf{2 0 2 1}$ \\
\hline Japan & 0.7 & -5.2 & 3 \\
\hline China & 6.1 & 1.2 & 9.2 \\
\hline U.S. & 2.3 & -5.9 & 4.7 \\
\hline Eurozone & 1.2 & -7.5 & 4.7 \\
\hline World & 2.9 & -3 & 5.8 \\
\hline
\end{tabular}

Source: IMF, year on year, \%, 2020, 2021 estimates [10]. 
It is calculated that the recovery of emerging markets (China being a big contributor) to be much faster comparing with developed economies, but this differentiate path was predicted even before the Covid-19 crises. In the graphic below we can see the economic shock suffered first quarter 2020 and also the forecasts for the rest of 2020 and 2021. Nevertheless the risk of a second wave is highly unknown so the economic downturn could be worse.

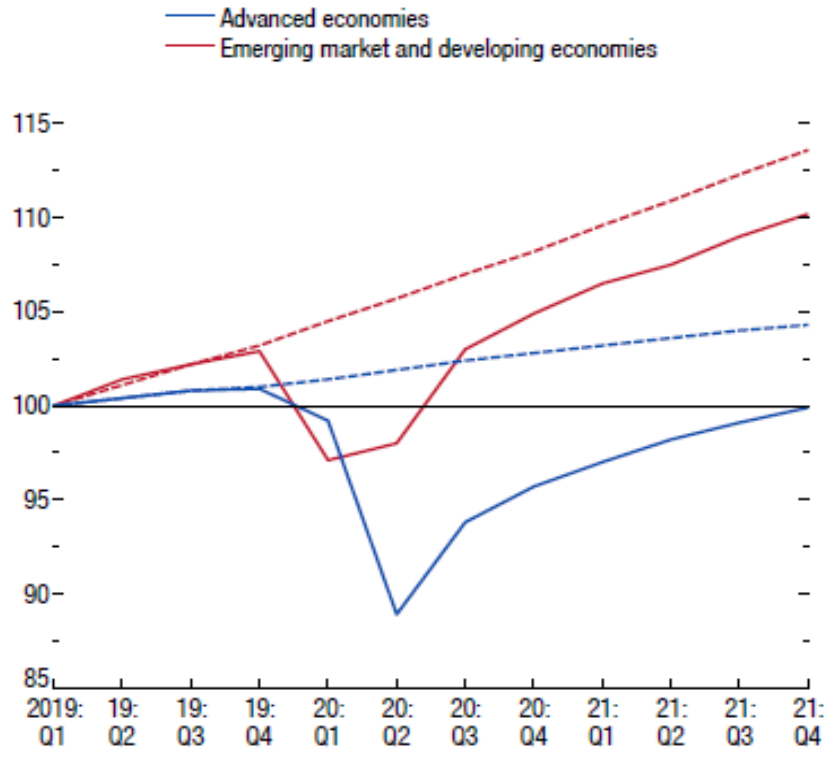

Fig. 2. World GDP- quarterly (estimation from January 2019 and 2020). Source: IMF estimates [11].

Despite its difficulties, U.S. seems ready to assert its vision for global leadership. At the height of the crisis, investors turned to the dollar, and the Fed's quick reaction proved decisive for the global financial markets, but there was little coordination with other countries and states - United States are now facing a massive task of revitalizing their national economy which will relegate most of the international objectives to the background. By definition, we may say that globalization, due to a very well-organized process of communication, transportation and trade is enabling the national or regional economies, societies and cultures to find a common ground, a way to promote each other and finally to gain mutually from extension of initial borders.

If we look at the overall picture of exports of goods and services we may say without hesitation that the world trading process is a very successfully story. Globalization, by all its tools - standardization, transportation and logistics infrastructure, information and communication technology, etc. allowed international companies doing businesses by interaction and sometime integration. 


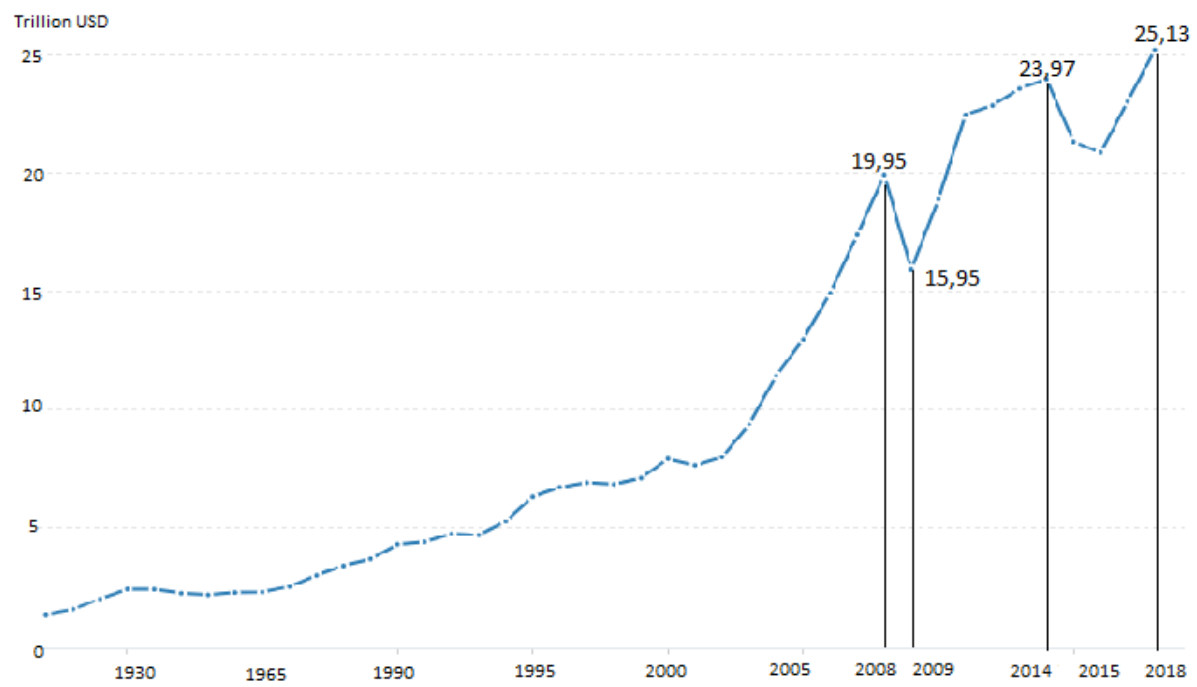

Fig. 3. Exports of goods and services, 1960-2018 Sources: International Monetary Fund, Balance of Payments Statistics Yearbook and data files [11].

Compared with global markets for goods and services, innovation has often been described as a case of "non-globalization" and remains concentrated in the countries of origin of multinational enterprises [12]. However, a large literature highlights that innovative activities develop more across national borders $[13,14]$. In addition, increasing attention is paid to the phenomenon of globalization of innovation because it is at the heart of the knowledge economy and the growing internationalization of value chains.

In addition, the globalization of innovation has many facets beyond the dissemination of innovative products throughout the world. On the one hand, innovative companies can cross borders in order to exploit abroad the innovations already developed in their country of origin while, on the other hand, companies can innovate on an international level in order to take advantage of foreign technological developments and acquire new skills.

From the graphic below we will understand that there is a continuing growth of innovation path, in term of new patents but also in term of international collaboration between different companies and research institutes.

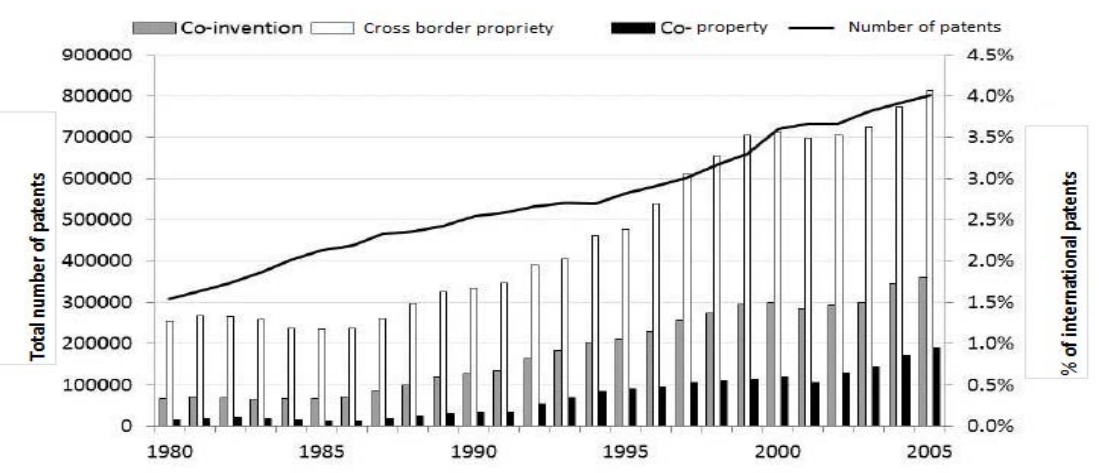

Fig. 4. The globalisation of innovation - patents evolution. Source: data bases of PATSTAT [15]. 
Additional results suggest that this increase in international collaborations can be explained both by a greater number of countries participating in international innovation projects and by a strengthening of the intensity of existing collaborations between partner countries. However, the intensity of globalization remains limited compared to all of the innovative activities - only $2 \%$ of international patent are registered. Still, the priority in this situation is given to those who are registering first. Globally from international co-invention projects, less than $5 \%$ of patents are cross-border property and $1 \%$ of patents are owned by companies from different countries.

Finding a vaccine or an efficient cure against Covid-19 is the most important thing that will restart the global economy. Of course, all the fiscal and financial measures are important in order to stabilize the situation and help the most affected people but a vaccine would definitely change the insecurity sentiment of the clients and workers. Therefore, an international collaboration and cooperation in the innovation and research would be in the benefit of the entire humankind, which is why globalization might be a solution and not a cause for this crisis.

Technology is ultimately going to shape the global economy more than the relationship between the United States and China. EU is also a very strong actor but at this moment it looks like is caught a bit in the middle, preserving its options in which direction to go. Probably the results of election from November 2020 in U.S. could be a decisive factor in this equation. Overall, business models were already changing before the crisis, with technology offering new solutions and influencing behaviour, from carpooling to the Internet of Things.

These transformations accelerated during the crisis. Video conferences, online shopping and cloud-based software have created a new way of working and becoming more efficient. More than any tariff war or geopolitical friction, innovation and digitalization will change the way the business world works.

With regard to the real challenges facing China, EU must take responsibility, rather than complain, and defend the national and European interests. It is needed to adopt a common policy accepted by all states, which is not the case at the moment.

However, it is clear that globalized world will change. If until now we thought that borders are not so important and big producing companies will not start moving their factories if something is happening in one country, during March 2020 we saw borders suddenly matter, few country (same of them being in very close friendly relation, as Germany, France, Italy) started to block shipments of medical equipment, tests and masks in order to build sufficient supplies. This crisis brings back the idea that basically the economic and political decisions are nation-state strongly related.

International companies created incredibly efficient supply chains by searching into the entire world the lowest prices to produce combined with best way of transportation. Still the system proved to be not sufficient diversified, not resilient and not resistant to interruption. Also, operating almost without or low inventories was good to increase margins but now it turn out that a medical problem shut dawn the entire economy.

The best example to understand the scale of the interconnections and repercussions of different disturbances over other global economic sectors is to remember that the price of oil reached -37.63 USD due to contraction of consumption (COVID-19 push factories to be closed and stopped people to travel) and the quantity oil war between Russia and Saudi Arabia. 


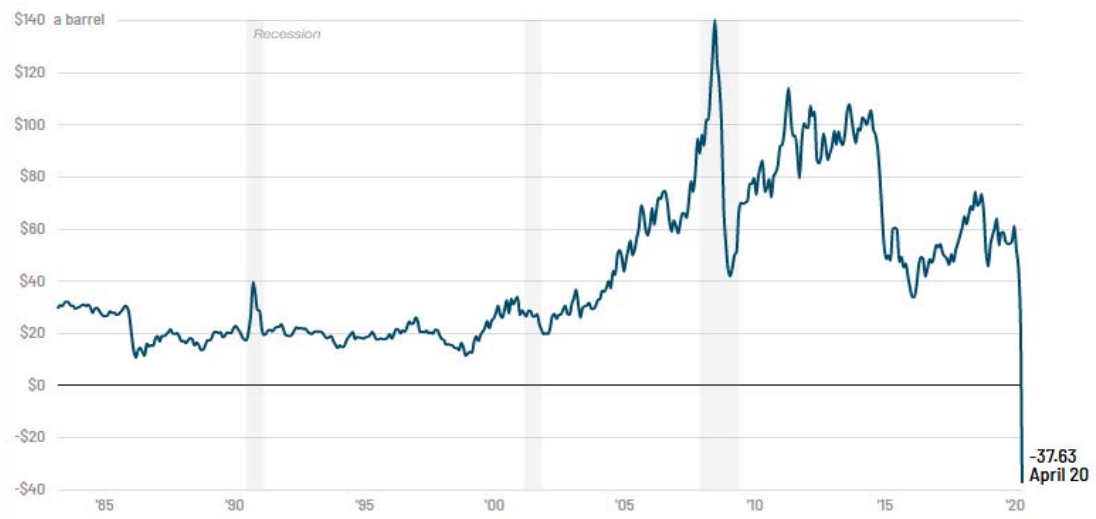

Fig. 5. U.S. light crude (May contract). Source: Refinitiv, [16].

Of course, the prices went back on the positive zone after that day, but it has been shown once again that managing industries with no buffer zones might be very dangerous and it may put the whole system down.

Apparently, we didn't learn too much from 2008 financial crisis when the interconnected financial system proved to be very fragile and only massive governments' interventions made that entire system to avoid the general collapse. We need to build a new economic system that should be more resilient to external shocks. Countries have to create a better equilibrium between picking up the fruits of globalization and the desideratum of keeping under control the economic environment.

One way or another, the Corona crisis will not bring the end of the globalization. It is much probable to see a certain shift, a limited version of global integration, with less economic connections, with more independency and growing importance of own inventories and resources. There will also be more frictions between states, their interests prevailing against general concerns and this will bring a higher overall cost in economy.

Anyway, we can certainly say that divergences started to appear even before pandemic (tariff war between U.S and China and U.S. and E.U., Brexit, populism and nationalism growing political currents, decoupling from China as a main producer of everything, $5 \mathrm{G}$ technology access, etc.) so the globalization process were already slowing its forces; Corona virus will only decelerate this movement, it is complicated to see the entire consequences for the moment.

An interesting indicator to look at is FDI which had its peak in 2007 at 3.136 trillion USD. The 2008 crisis brought it dawn and despite an important recovery it never came back at the same level. In 2018, according to World Bank and UNCTAD data, the value of inward direct investment made by non-resident investors in the global economy was 1.195 trillion USD, the same value as 1995. This is a clear indication that, in the last years, there is a certain path of retention in investing money in other country than the origin one. Some specialists are arguing that the increasing FDI period was not sustainable but this is another discussion. 


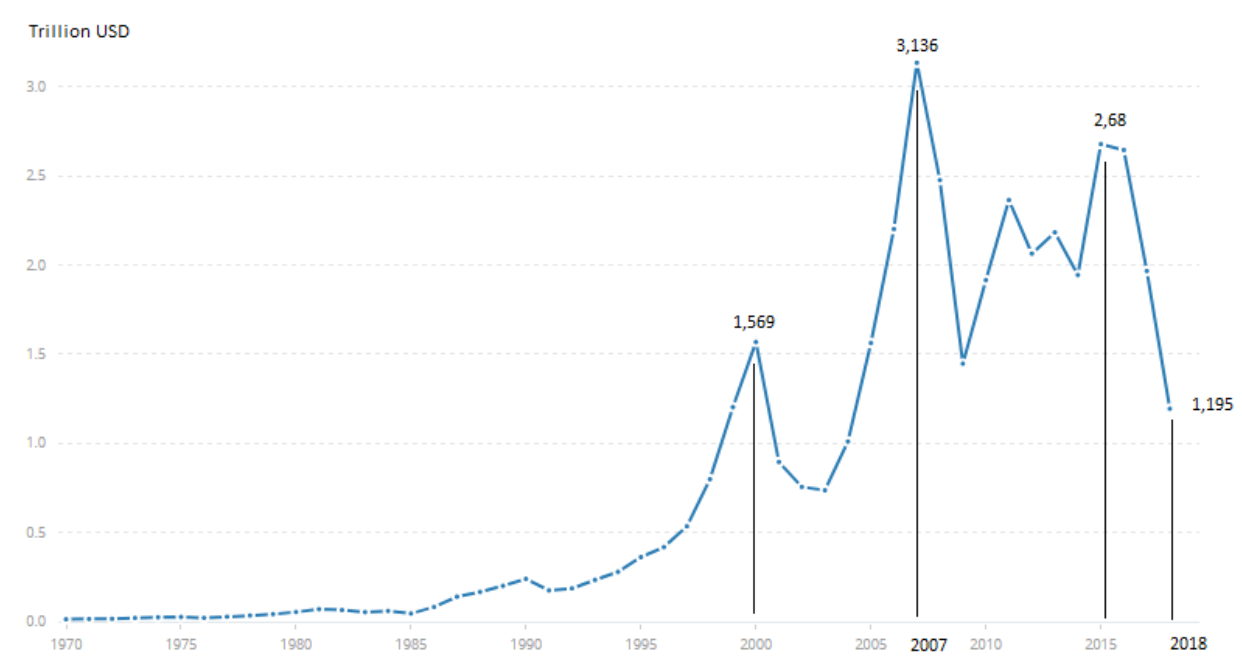

Fig. 6. Foreign direct investment, net inflows, 1970-2018 Source: World Bank data [17].

\section{Conclusion}

In a global world, we can see that borders do not protect against a pandemic and that all the major challenges facing humanity can only be solved by multilateral systems and by multilateral negotiation. International institutions are today what Churchill said of democracy "the worst system to the exclusion of all the others". There are plenty of negative thoughts that may be given to international organisations (World Health Organization being very much criticised during this period) but it is not easy to imagine another solution in order to make people find a way to go through.

It is easy to put the blame on globalization for virus spreading but the reality shows that we have greater benefits from cooperation, collaboration and integration. Even finding a vaccine against Covid-19 can be done faster and efficient due to exchanging experiences, data, technologies, etc. It is also true that some steps back were done in the recent years, few states decided to take the control of their borders and other to exchange the tariffs trade so the slowdown of the globalization is rather a trend started before.

In any case, we will certainly be witnesses of the new direction of globalization, from one side the new technological wave dominated by numerical technologies, internet of things, connected machines, socializing networks, etc. and from the other side the need of security (social, medical, food), independency and stability. It will certainly be not a step back but a step in another direction.

\section{References}

1. Bran, F., Rădulescu, C. V., Bodislav, D. A., Burlacu, S. (2020). Environmental risks in the context of globalization. Economic Convergence in European Union, 350.

2. Dobre, I., Jianu, I., Bodislav, D. A., Radulescu, C. V., Burlacu, S. (2019). The Implications of Institutional Specificities on the Income Inequalities Drivers in European Union. Economic Computation and Economic Cybernetics Studies and Research, 53(2), $59-76$. 
3. Bodislav, D. A., Buzoianu, O. A. C., Burlacu, S., Rădulescu, C. V. (2020). Analysis of companies in Romania from the perspective of risk perception and the management needs thereof. Economic Convergence in European Union, 341.

4. Burlacu, S., Gutu, C., Matei, F. O. (2018). Globalization - Pros and Cons. Quality-Access to Success, 19(1), 122-125.

5. Burlacu, S., Bodislav, D. A., Rădulescu, C. V. (2018). E-commerce and Global Food Resources. Managerial Challenges of the Contemporary Society. Proceedings, 11(2), 48.

6. Alpopi, C., Burlacu, S., Ioviţu, M. (2018). Procesul de globalizare şi politicile ecologice. Competitivitatea şi Inovarea în Economia Cunoaşterii (pp. 317-324). Chișinău, Republica Moldova: Departamentul Editorial-Poligrafic al ASEM.

7. Ionita, F., Ursacescu, M., Burlacu, S. (2009). Public Services as Poles of Regional Competitiveness in Sustainable Development. Management Comparat International/Review of International Comparative Management, 10(3), 552-565.

8. Oqubay, A., Lin Yifu, J. (2019). China - Africa and Economic Transformation. Oxford: University Press.

9. Sun, I. Y., Jayaram, K., Kassiri, O. (2017). Dance of the lions and dragons. How are Africa and China engaging, and how will the partnership evolve? Retrieved from: https://www.mckinsey.com/featured-insights/middle-east-and-africa/the-closest-lookyet-at-chinese-economic-engagement-in-africa

10. I.M.F. (April 2020). World Economic Outlook, April 2020: The Great Lockdown Retrieved from: https://www.imf.org/en/Publications/WEO/Issues/2020/04/14/weoapril-2020

11. I.M.F. (2019). Balance of Payments Statistics Yearbook and data files. Retrieved from: https://data.worldbank.org/indicator/BX.GSR.GNFS.CD

12. Patel, P., Pavitt, K. (1991). Large Firms in the Production of the World's Technology: An Important Case of "Non-Globalisation". Journal of International Business Studies, $22,1-21$.

13. U.N.C.T.A.D. (2018). Creative Economy Outlook: Trends in international trade in creative industries. Retrieved from: https://unctad.org/en/PublicationsLibrary/ ditcted2018d3_en.pdf

14. UNESCO (2013). Creative economy report. Widening local development pathways. Retrieved from: http://www.unesco.org/culture/pdf/creative-economy-report-2013.pdf

15. Danguy, J. (2016). La globalisation de l'innovation analysée par les données de brevets. Reflets et perspectives de la vie économique, 2, 17-26.

16. Egan, M. (2020). How negative oil prices could set the stage for the next price boom. Retrieved from: https://edition.cnn.com/2020/04/22/business/negative-oil-pricesspike/index.html

17. I.M.F. (2019). Balance of Payments database, supplemented by data from the United Nations Conference on Trade and Development and official national sources. Retrieved from: https://data.worldbank.org/indicator/BX.KLT.DINV.CD.WD 